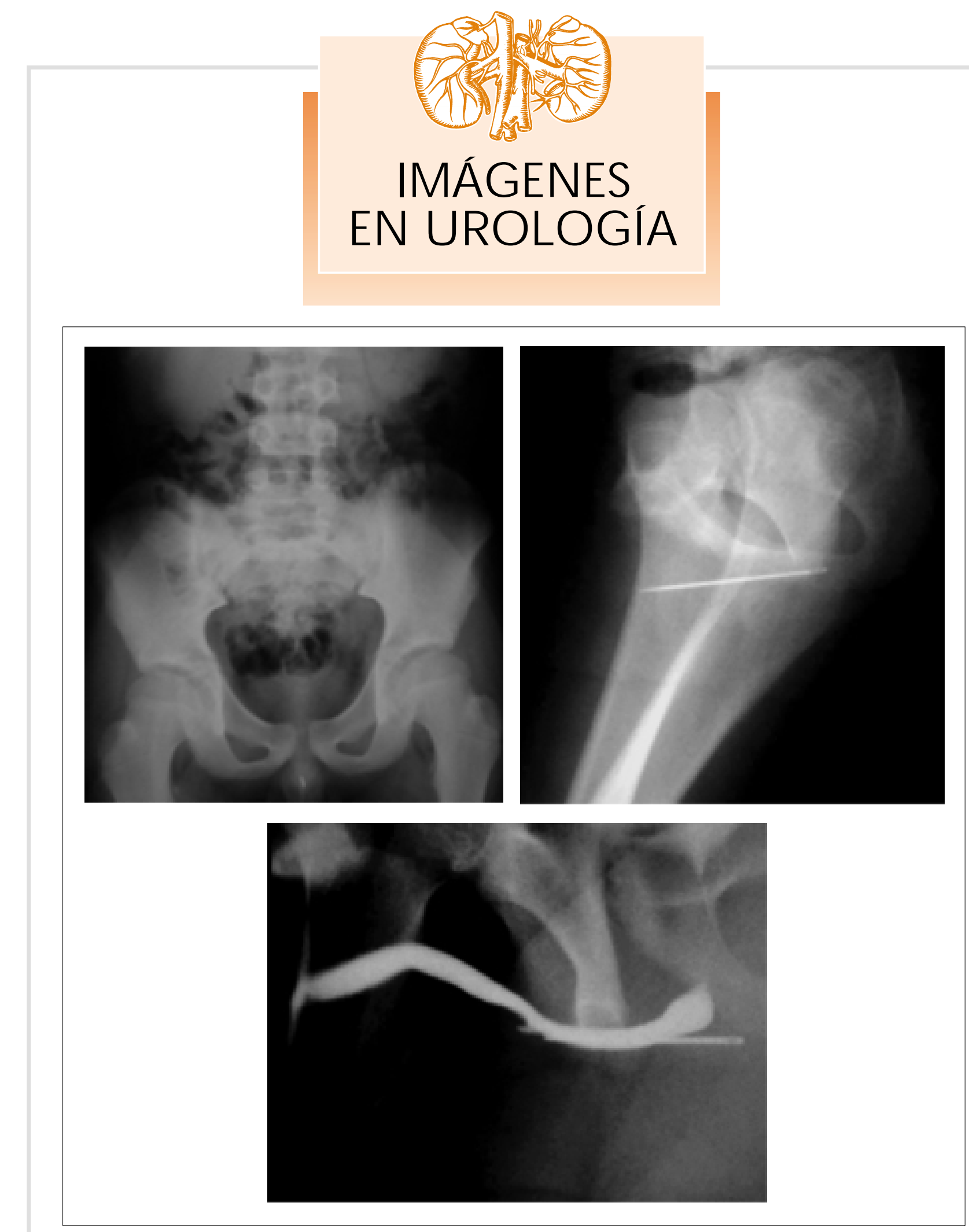

\title{
CUERPO EXTRAÑO URETRAL
}

Uretrorragia en varón de 9 años. Radiografía de abdomen anteroposterior, radiografia pélvica lateral y uretrografía retrógrada evidenciando aguja de costura clavada en uretra bulbar.

S. Garrido Insua, F. Estudillo González, F. Rodríguez-Rubio.

Servicio de Urología. Hospital Universitario de Puerto Real. Cádiz. 